Pesq. Vet. Bras. 29(1):29-32, janeiro 2009

\title{
Neospora caninum seropositivity in cattle breeds in the South Fluminense Paraíba Valley, state of Rio de Janeiro ${ }^{1}$
}

\author{
Alexandre D. Munhoz ${ }^{2}$, Maria Júlia S. Pereira ${ }^{3}$, Walter Flausino ${ }^{3}$ and \\ Carlos Wilson G. Lopes ${ }^{3^{*}}$
}

\begin{abstract}
Munhoz A.D., Pereira M.J.S., Flausino W. \& Lopes C.W.G. 2009. Neospora caninum seropositivity in cattle breeds in the South Fluminense Paraíba Valley, state of Rio de Janeiro. Pesquisa Veterinária Brasileira 29(1):29-32. Departamento de Parasitologia Animal, Instituto de Veterinária, Universidade Federal Rural do Rio de Janeiro, Seropédica, RJ 23890-000, Brazil. E-mail: lopescwg@ufrrj.br

The infection by Neospora caninum of different cattle breeds in dairy properties in two municipalities of the South Fluminense Paraíba Valley, state of Rio de Janeiro, was evaluated. Considering a sampling universe of 2,491 cows, blood samples were collected from 563 dairy cows in 57 farms, which were randomically selected in proportion to the number of animals, using a random stratified sampling system. For each property the number of selected cows was proportional to the herd size. Abortion or other reproductive disorders were not considered as criteria for selecting the animals, and seropositivity was determined by indirect enzyme-linked immunosorbent assay (ELISA). A high association $(p=0.006)$ between seropositivity and racial patterns was found. The analysis revealed that in comparison of pure black-and-white Holstein cows versus Zebu $(p=0.0028)$, Holstein cows showed 2.65 times greater odds for seropositivity. In the same way, by comparing black-and-white Holstein versus Zebu + crossbreed Zebu/Holstein $(p=0.01)$, it was noted that there is 2.23 times more chance for seropositivity in Holstein cattle. There were no significant differences concerning the comparison of Holstein cattle versus crossbreed Zebu/Holstein $(p=0.08)$ or Zebu versus crossbreed Zebu/Holstein $(p=0.11)$. This study supports the hypothesis that there is a close association between cattle breeds and the frequency of infection by $N$. caninum.
\end{abstract}

INDEX TERMS: Neospora caninum, association, cattle breed.

RESUMO.- [Soropositividade para Neospora caninum e raças bovinas no vale do Paraíba sulfluminense, Estado do Rio de Janeiro.] A realização deste estudo teve como objetivo verificar a ocorrência diferenças na distribuição da infecção por Neospora caninum em bovinos leiteiros da raça Holandesa Preta e Branca e mestiços na Mesorregião Fluminense a maior bacia leiteira do Rio de Janeiro. De um total de 2.491 vacas foram coleta-

\footnotetext{
${ }^{1}$ Received on September 20, 2007.

Accepted for publication on August 4, 2008.

Supported by CNPq and FAPERJ

${ }^{2}$ Laboratório de Análises Clínicas Veterinárias, Departamento de Ciências Agrárias e Ambientais, Universidade Estadual de Santa Cruz, Ilhéus, BA 45650-000, Brazil.

${ }^{3}$ Departamento de Parasitologia Animal, Instituto de Veterinária, Universidade Federal do Rio de Janeiro, Seropédica, RJ 23890-000, Brazil; bolsista do CNPq. *Corresponding author: lopescwg@ufrrj.br
}

das amostras de sangue de 563 de forma não randomizada, pertencentes a 57 propriedades localizadas nos municípios de Resende e Rio Claro. O tamanho da amostra por propriedade foi proporcional ao número de animais alvo da mesma. O abortamento ou distúrbios reprodutivos não foram utilizados como critérios de seleção. Foi verificada associação altamente significativa entre a soropositividade e o padrão racial $(p=0,006)$. Ao conduzir as análises entre apenas dois padrões verificou-se os seguintes resultados: HPB versus zebuínos $(p=0,0028)$ com 2,65 mais chances de sorpositividade em bovinos HPB; HPB versus (zebuínos + Gir x Holandês) $p=0,01$, com 2,23 mais chances de sopositividade também na raça HPB. Não houve diferença significativa entre HPB versus Gir x Holandês $(p=0,08)$ e entre os zebuínos e Gir x Holandês $(p=0,11)$. Este estudo suporta a hipótese que existe uma estreita relação entre a presença da infecção e a 
raça européia Holandesa Preta e Branca, na região e condições em que foi desenvolvido o presente estudo.

TERMOS DE INDEXAÇÃO: Neospora caninum, associação, padrões bovinos.

\section{INTRODUCTION}

Since its identification in 1988, many aspects of the biology, diagnosis and control of Neospora caninum, have been investigated (Dubey 1999; 2003) due to its importance as a causative agent of abortion in cattle. Despite many reports of abortion outbreaks in beef cattle (Waldner et al. 1999, McAllister et al. 2000), this phenomenon has occurred worldwide mostly in dairy cattle (Dubey 1999, Wouda et al. 1997, Reichel 2000).

In the $N$. caninum life cycle, dogs and coyotes are definitive hosts (McAllister et al. 1998, Lindsay et al. 1999, Gondim et al. 2004). The vertical transmission is the main form of dissemination and responsible for the maintenance of infection by N. caninum among flocks (Paré et al.1996, Thurmond Hietala 1997, Davison et al. 1999).

Once $N$. caninum is identified as the bioagent responsible for abortions, dogs must be maintained as distant as possible from the cattle and cows' fetal material (Wouda et al. 1999, Dijkstra et al. 2002b,c) in order to prevent extreme economic measures such as the discharge of seropositive animals (Tress et al. 1999). However the literature reports that there is a high number of seropositive flocks without clinical neosporosis (Dijkstra et al. 2002a, Munhoz et al. 2003). This indicates the existence of inner and outer protection factors.

Brazilian studies have contributed to the knowledge of distribution of infection in cows (Gennari 2004), its association with cases of abortion (Locatelli-Dittrich et al. 2001, Corbellini et al. 2002), its risk factors (Melo et al. 2001, Guimarães Júnior et al. 2004), and the isolation of the parasite (Gondim et al. 2001) . However, there is much more to be investigated, since Brazilian territory has a wide climate variation with many different ecosystems, what implicates a great diversity in the breed population according to the geographic areas which could affect the distribution of neosporosis.

Taking into consideration these aspects, the aim of this study was to investigate potential association between the distribution of infection by N. caninum and different breeds of dairy cattle in the municipalities of Resende and Rio Claro, in the South-Fluminense Paraiba Valley, state of Rio de Janeiro. The research verified the occurrence of differences in the distribution of the infection by $N$. caninum in black and white Holstein and crossbreed dairy cattle.

\section{MATERIALS AND METHODS}

\section{Municipalities}

The study was carried out in farms located at the municipalities of Resende (Altitude $407 \mathrm{~m}$, South latitude $22^{\circ} 28^{\prime} 08^{\prime \prime}$ and West longitude $44^{\circ} 26^{\prime} 48^{\prime \prime}$ ) totaling a $1,100.2 \mathrm{Km}^{2}$ area, and Rio Claro (Altitude 446m, South latitude $22^{\circ} 43^{\prime} 23^{\prime \prime}$ and West longitude $44^{\circ} 08^{\prime} 08^{\prime \prime}$ ), totaling a $843.4 \mathrm{~km}^{2}$ area, located at the valley of Paraíba do Sul river, in the State of Rio de Janeiro (CIDE 2001), the largest dairy region of this State (IBGE 2004).

\section{Source of data}

The cadastral information of each property, obtained from the office of the local Animal Health Defense Service in Resende and at Emater-Rio Claro, was used to collect data concerning number and size of the farms. Samples were taken form 453 farms with the same productive dairy characteristics, and a total of 2,491 dairy cows, more than 3 years old, were selected. The study was undertaken from August 2001 to May 2003. The estimate prevalence $(p)$ used to calculate the range of the farm samples was based on previous studies (Gondim et al. 1999, Melo et al. 2001). Thus, a $p=93.65 \%$, and an error type I=8.65\% were used to calculate the number of farms; and a $p=16.69 \%$, and an error $=4.69 \%$ were used to calculate the number of animals, both with a $95 \%$ confidence interval $(\mathrm{Cl})$. The EPI Info 2000 (Dean \& Arnet 2002) software was used to confirm these estimates, and the results found were 57 farms and 563 animals. Farms were selected randomically, whereas animals were selected by convenience during the milk extraction period.

Although abortion and other reproductive disturbs can occur due to neosporosis, (Dubey 1999a,b), these criteria were not considered when the farms and animals were selected.

\section{Samples and laboratorial analysis}

All analysis were carried out at Laboratório de Coccídios e Coccidioses (Projeto Sanidade Animal Embrapa/UFRRJ), Departamento de Parasitologia Animal, Instituto de Veterinária da Universidade Federal Rural do Rio de Janeiro (UFRRJ). Blood samples were collected through punction of the mammary vein; after coagulation, the samples were centrifuged at $350 \mathrm{~g}$ for 10 minutes to recover sera, kept in $2.0 \mathrm{~mL}$ cryotubes, duplicated and stored at $-20{ }^{\circ} \mathrm{C}$ until analysis. To detect anti-Neospora caninum antibodies, an indirect ELISA (Herdcheckâ, IDEXX Laboratories Inc. EUA) was used, according to the description of Paré et al. (1995). The cutoff was defined negative for S/P ratio $<0.5$, whereas $S / P$ ratio ${ }^{3} 0.5$ was considered positive.

\section{Statistical analysis}

In order to associate results of serology with cattle breeds, a $c^{2}$ test with Yates correction (Sampaio 1998, Dean \& Arner 2002) was used.

\section{RESULTS}

In the present study three types of breeds were investigated: Pure Black and White Holstein, Zebu and crossbreeds (Zebu/Holstein), with a range from 1/2 blood until $7 / 8$ of Holstein cattle. Considering the total of selected cows, $55(9.8 \%)$ were black and white Holstein, 222 (39.4\%) Zebu, and 286 (50.8\%) crossbreeds, from 57 farms. (Table 1)

A close association between seropositivity for Neospora caninum infection and breeds $(p=0.006)$ was observed (Table 2). After the comparison (2x2) of breeds, it was noted that: for black and white Holstein versus Zebu $(p=0.0028)$ there was 2.65 times more chance for seropositivity in black and white Holstein cows; for Black and 
Table 1. Distribution of pure breed, crossbreeds and properties in the South Fluminense Paraíba Valley, Rio de Janeiro, according to anti-Neospora caninum serum positive animals

\begin{tabular}{|c|c|c|c|c|}
\hline \multirow{2}{*}{ Breed and crossbreeds } & \multirow{2}{*}{$\begin{array}{c}\text { Number of } \\
\text { animals }^{a}\end{array}$} & \multicolumn{2}{|c|}{ Dairy farms } & \multirow{2}{*}{$\begin{array}{l}\text { Numbers } \\
\text { of farms }\end{array}$} \\
\hline & & Positive & Negative & \\
\hline Holstein Black & & & & \\
\hline & & & & 5.1) \\
\hline Zel & & & & 57.9) \\
\hline Total & $563(100)$ & $50(87.7)$ & 7 (12.3) & $57(100)$ \\
\hline
\end{tabular}

a Percentage in parenthesis.

Table 2. Number of Neospora caninum serum positive cattle in the South Fluminense Paraiba Valley, Rio de Janeiro

\begin{tabular}{lccc}
\hline \multirow{2}{*}{ Breed and Cross breed } & \multicolumn{2}{c}{ Neospora caninum } & \multirow{2}{*}{ Total } \\
\cline { 2 - 3 } & Positive & Negative & \\
\hline Holstein Black and White & $21(38.2)$ & $34(61.4)$ & $55(9.8)$ \\
Cross breed & $56(25.2)$ & $166(74.8)$ & $222(39.4)$ \\
Zebu & $54(18.9)$ & $232(81.1)$ & $286(50.8)$ \\
Total & $131(23.3)$ & $432(76.7)$ & $563(100)$ \\
\hline
\end{tabular}

a Percentage in parenthesis $(p=0.006)$.

Table 3. Odds ratio of Neospora caninum serum positive cattle in the South Fluminense ParaíbaValley, Rio de Janeiro

\begin{tabular}{lccc}
\hline \multicolumn{1}{c}{ Breed and Cross breed } & $\chi^{2}$ & Odds Ratio $(95 \%)$ & $\mathrm{p}^{\mathrm{a}}$ \\
\hline Holstein Black and & 8.92 & $2.65(1.36<\mathrm{OR}>5.15)$ & 0.003 \\
White (HBW) x Zebu & & & \\
HBW x (Zebu + Crossbreed) & 6.70 & $2.23(1.20<\mathrm{OR}>4.16)$ & 0.01 \\
HBW x Crossbreed & 3.07 & $1.83(0.94<\mathrm{OR}>3.57)$ & 0.08 \\
Crossbreed x Zebu & 2.60 & $1.45(0.93<\mathrm{OR}>2.26)$ & 0.11
\end{tabular}

a Yates correction.

white Holstein versus (Zebu + crossbreed Zebu/Holstein) $p=0.01$ there was 2.23 times more chance for seropositivity also in Holstein. No significant differences (Table 3) between black and white Holstein versus crossbreed Zebu/ Holstein $(p=0.08)$ or crossbreed Zebu versus crossbreed Zebu/Holstein $(p=0.11)$ were found.

\section{DISCUSSION}

The results indicate that breed, which is an inherent factor to hosts, can be considered of high relevance for the distribution and frequency of infection by Neospora caninum. The genetic distance between Holstein and Zebu breeds possibly leads to the significant difference (Table 3).

In Denmark, Jensen et al. (1999), investigating the association between dairy breeds and abortion, did not verify significant relevance between those categories. However, these authors did not evaluate the seropositivity against breeds. In France, an association between frequency of neosporosis and the type of herd (for beef or milk) also proved not significant (Ould-Amrouche et al.
1999), but this study did not include different levels of crossbreed in dairy cattle.

In Brazil, similar results, such as the present study, have been reported. Guimarães Júnior et al. (2004) found high difference ( $\mathrm{p} £ 0.001$ ) in the proportion of seropositive black and white Holstein cows against mixed breed cattle with 2.13 times more chance for seropositivity. Nevertheless, as cited by these authors, there is a possibility that this finding is due to the small number of crossbreed cows tested. Differently in the present investigation, a positive association is maintained despite that the farms characteristic for the region studied are constituted of a larger number of crossbreeds than purebred Holstein. These results were similar to those presented by Pan et al. (2004), who reported a genetic susceptibility to infection by $N$. caninum of Holstein cattle. They also suggested that a genetic base selection could reduce the incidence of infection in livestock. The occurrence of similar results in different geographic areas with a distinct condition of breeds indicates that breeds are important in the evaluation of infection by N. caninum. Few studies have been carried out considering breed as an epidemiological parameter, to understand the distribution of the infection by $N$. caninum in dairy cattle, probably due to the fact that most of the surveys are restricted to pure breed cattle or to very similar breeds.

\section{CONCLUSION}

The results of this study support the hypothesis that there is a close association between cattle breed and the frequency of infection by Neospora caninum.

Acknowledgements.- To CNPq (National Council for Technological and Research Development), FAPERJ (Research Foundation of the State of Rio de Janeiro) for financial support, and to the Emater-Rio Veterinarians Rogério Teixeira da Silva and Cláudio Rodrigues Rocha de Almeida, for their technical assistance.

\section{REFERENCES}

Corbellini L.G., Driemeier D., Cruz C.F.E., Gondim L.F.P. \& Wald V. 2002. Neosporosis as cause of abortion in dairy cattle in Rio Grande do Sul, southern Brazil. Vet. Parasitol. 103:195-202.

Davison H.C., Otter A. \& Trees A.J. 1999. Estimation of vertical and horizontal transmission parameters of Neospora caninum infection in dairy cattle. Int. J. Parasitol. 29:1683-1689.

Dean A.G. \& Arner T. 2002. Epi Info: Epidemiology of program office. Available on: <http://www.cdc.gov/epiinfo/index.html>. Access: April 20, 2002.

Dubey J.P. 1999a. Recents advances in Neospora and neosporosis. Vet. Parasitol. 84:349-367.

Dubey J.P. 1999b. Neosporosis in cattle: Biology and economic impact. J. Am. Vet. Med. Assoc. 214:1160-1163.

Dubey J.P. 2003. Review of Neospora caninum and neosporosis in animals. Korean J. Parasitol. 41:1-16.

Dijkstra T.H., Barkema H.W., Bjorkman C. \& Wouda W. 2002a. A high rate of seroconversion for Neospora caninum in a dairy herd with out an obvious increased incidence of abortions. Vet. Parasitol. 109:203211.

Dijkstra T.H., Barkema H.W., Eysker M., Hesselink J.W. \& Wouda W. 
2002b. Natural transmission routes of Neospora caninum between farm dogs and cattle. Vet. Parasitol. 105:99-104.

Dijkstra T.H., Barkema H.W., Hesselink J.W. \& Wouda W. 2002c. Point source exposure of cattle to Neospora caninum consistent with periods of common housing and feeding and related to the introduction of a dog. Vet. Parasitol. 105:89-98.

CIDE 1998. Estado do Rio de Janeiro: Território. $2^{\underline{a}}$ ed. Fundação Centro de Informações e Dados do Rio de Janeiro, Rio de Janeiro. 80p.

Gennari S.M. 2004. Neospora caninum no Brasil: Situação atual da pesquisa. Revta Bras. Parasitol. Vet. 13(Supl.1):23-28.

Gondim L.F.P., Sartor I.F., Hasegawa M. \& Yamane I. 1999. Serumprevalence of Neospora caninum in dairy cattle in Bahia, Brazil. Vet. Parasitol. 86:71-75.

Gondim L.F.P., Pinheiro A.M., Santos P.O.M., Jesus E.E.V., Ribeiro M.R., Fernandes H.S., Almeida M.A.O., Freire S.M., Meyer R. \& McAllister M.M. 2001. Isolation of Neospora caninum from the brain of a naturally infected dog, and production of encysted bradzoites in gerbils. Vet. Parasitol. 98:1-7.

Gondim L.F.P., McAllister M.M., Pittb W.C. \& Zemlickac D.E. 2004. Coyotes (Canis familiaris) are definitive hosts of Neospora caninum. Int. J. Parasitol. 34:159-161.

Guimarães Jr J.S., Souza S.L.P., Bergamaschi D.P. \& Gennari S.M. 2004. Prevalence of Neospora caninum and factors associated with their presence in dairy cattle of the north of Paraná state, Brazil. Vet. Parasitol. 124:1-8.

IBGE 2002. Produção da Pecuária Municipal. Instituto Brasileiro de Geografia e Estatística. Available on: <http//:www.sidra.ibge.gov.br>. Access: Jan. 30, 2004.

Jenkins M., Baszler T., Björman C., Schares G. \& Williams D. 2002. Diagnosis and seroepidemiology of Neospora caninum-associated bovine abortion. Int. J. Parasitol. 32:631-636.

Jensen A.M., Bjorkman C., Kjeldsen A.M., Wedderkopp A., Willadsen C., Uggla A. \& Lund P. 1999. Association of Neospora caninum seropositivity with gestation number and pregnancy outcome in Danish dairy herds. Prev. Vet. Med. 40:151-163.

Lindsay D.S., Dubey J.P. \& Duncan R.B. 1999. Confirmation that the dog is a definitive host for Neospora caninum. Vet. Parasitol. 82:327-333

Locatelli-Dittrich R., Soccol V.T., Richartz R.R., Gasino-Joineau M.E., Vinne R. \& Pinckney R.D. 2001. Serological diagnosis of neosporosis in a dairy herd of dairy cattle in southern Brazil. J. Parasitol. 87:14931494.

McAllister M., Dubey J.P., Lindsay D., Jolley W., Wills R. \& McGuire A. 1998. Dogs are definitive hosts of Neospora caninum. Int. J. Parasitol. 28:1473-1478.

McAllister M.M., Bjorkman C., Anderson-Sprecher R. \& Rogers D.G.
2000. Evidence of point-source exposure to Neospora caninum and protective immunity in a herd of beef cows. J. Am. Vet. Med. Assoc. 217:881-887.

Melo C.B., Leite R.C., Souza G.N. \& Leite R.C. 2001. Freqüência de infecção por Neospora caninum em dois diferentes sistemas de produção de leite e fatores predisponentes à infecção em bovinos em Minas Gerais. Revta Bras. Parasitol. Vet. 10:67-74.

Munhoz A.D., Flausino W., Silva R.T., Almeida C.R.R., Teixeira M., Albuquerque G.R. \& Lopes C.W.G. 2003. Anticorpos contra Neospora caninum em vacas, no rebanho leiteiro da Mesorregião Sul Fluminense, Estado do Rio de Janeiro. Revta Bras. Reprod. Anim. 27:643-646

Pan Y., Jansen G.B., Duffield T.F., Hietala S., Kelton D., Lin C.Y. \& Peregrine A.S. 2004. Genetic Susceptibility to Neospora caninum infection in Holstein Cattle in Ontario. J. Dairy Sci. 87:3967-3975.

Paré J., Thurmond M.C. \& Hietalla S.K. 1996. Congenital Neospora caninum infection in dairy cattle and associated calf hood mortality. Can. J. Vet. Res. 60:133-139.

Ould-Amrouche A., Klein F., Osdoit C., Mohammed H.O., Touratier A., Sanaa M. \& Mialot J.P. 1999. Estimation of Neospora caninum seroprevalence in dairy cattle from Normandy, France. Vet. Res. 30:531538.

Reichel M.P. 2000. Neospora caninum infections in Australia and New Zealand. Aust. Vet. J. 78:258-261

Sampaio I.B.M. 1998. Estatística Aplicada à Experimentação Animal. Fundação de Ensino e Pesquisa em Medicina Veterinária e Zootecnia, Belo Horizonte. 221p.

Thurmond M.C. \& Hietalla S.K. 1997. Effect of congenitally-acquired Neospora caninum infection on risk of abortion and subsequent abortions in dairy cattle. Am. J. Vet. Res. 58:1381-1385.

Tress A.J., Davison H.C., Innes E.A. \& Wastling J.M. 1999.Towards evaluating the economic impact of bovine neosporosis. Int. J. Parasitol. 29:1195-1200.

Waldner C.L., Janzen E.D., Henderson J. \& Haines D.M. 1999. Outbreak of abortion associated with Neospora caninum infection in a beef herd. J. Am. Vet. Med. Assoc. 215:1485-1490.

Wouda W., Moen A.R., Visser U. \& Van Knapen F. 1997. Bovine fetal neosporosis: Comparison of epizootic and sporadic abortion cases and different age classes with regard to lesion severity and immunohistochemical identification of organisms in brain, heart, and liver. J. Vet. Diag. Invest. 9:180-185.

Wouda W., Dijkstra T.P., Kramer A.M.H., Van Maanen C. \& Brinkhof J.M.A. 1999. Seroepidemiological evidence for a relationship between Neospora caninum infections in dogs and cattle. Int. J. Parasitol. 29:1677-1682. 